\title{
Predicting long-term recovery of a strongly acidified stream using MAGIC and climate models (Litavka, Czech Republic)
}

\author{
D. W. Hardekopf ${ }^{1}$, J. Horecký ${ }^{1}$, J. Kopáček ${ }^{2}$, and E. Stuchlík ${ }^{1}$ \\ ${ }^{1}$ Institute for Environmental Studies, Faculty of Science, Charles University in Prague, Benátská 2, 12801, Prague 2, Czech \\ Republic \\ ${ }^{2}$ Hydrobiological Institute, Academy of Sciences of the Czech Republic, and Faculty of Biological Sciences, University of \\ South Bohemia, Na Sádkách 7, 37005, České Budějovice, Czech Republic
}

Received: 1 December 2006 - Published in Hydrol. Earth Syst. Sci. Discuss.: 11 September 2007

Revised: 18 January 2008 - Accepted: 5 February 2008 - Published: 5 March 2008

\begin{abstract}
Two branches forming the headwaters of a stream in the Czech Republic were studied. Both streams have similar catchment characteristics and historical deposition; however one is rain-fed and strongly affected by acid atmospheric deposition, the other spring-fed and only moderately acidified. The MAGIC model was used to reconstruct past stream water and soil chemistry of the rain-fed branch, and predict future recovery up to 2050 under current proposed emissions levels. A future increase in air temperature calculated by a regional climate model was then used to derive climate-related scenarios to test possible factors affecting chemical recovery up to 2100. Macroinvertebrates were sampled from both branches, and differences in stream chemistry were reflected in the community structures. According to modelled forecasts, recovery of the rain-fed branch will be gradual and limited, and continued high levels of sulphate release from the soils will continue to dominate stream water chemistry, while scenarios related to a predicted increase in temperature will have little impact. The likelihood of colonization of species from the spring-fed branch was evaluated considering the predicted extent of chemical recovery. The results suggest that the possibility of colonization of species from the spring-fed branch to the rain-fed will be limited to only the acid-tolerant stonefly, caddisfly and dipteran taxa in the modelled period.
\end{abstract}

\section{Introduction}

Acidification of surface waters in sensitive regions due to extremely high emissions of sulphur (S) and nitrogen $(\mathrm{N})$ compounds has been well documented in Central Europe

Correspondence to: D. W. Hardekopf

(davidh@ natur.cuni.cz)
(Moldan and Schnoor, 1992; Fott et al., 1994). Large reductions in S and N inputs in the 1980s and 1990s have resulted in significant reversal of acidification in some of these fresh waters (Veselý et al., 2002). Dynamic models have been successfully applied to many catchments in the region (Majer et al., 2003; Hruška and Krám, 2003; Kopáček et al., 2004a) and have proven to be robust in predicting changes in soil and water chemistry in response to the decreased deposition. Future predictions based on expected atmospheric emission reductions required under European Union agreements (Gothenburg Protocol - UN-ECE, 1999), however, show that recovery of these ecosystems is complicated by continued leaching of sulphate $\left(\mathrm{SO}_{4}\right)$, and in some cases nitrate $\left(\mathrm{NO}_{3}\right)$, from soils exposed to long-term deposition of these compounds (Kopáček et al., 2002; Hruška et al., 2002). Although acidification in the former Czechoslovakia was first recognized in the more intensively studied border mountain areas (Fott et al., 1987), a study on the distribution of acidification in the Czech Republic (Veselý and Majer, 1996) showed that the Brdy Mountain region in the central part of the country was among the most anthropogenically acidified areas. The headwater region of one of the streams originating in these mountains, the Litavka River, consists of two branches in the first two kilometres. Both streams have similar catchment characteristics and historical exposure to acid atmospheric deposition. One branch, however, is rain-fed and strongly acidified, with current $\mathrm{pH}$ around 4.1 and high levels of reactive aluminium $\left(\mathrm{Al}_{R}\right.$, sensu Driscoll, 1984). The other branch is spring-fed, and currently has an average $\mathrm{pH}$ of 5.6, with low concentrations of $\mathrm{Al}_{R}$. The MAGIC model was applied to the rain-fed catchment to reconstruct historical soil and stream water chemistry, and to predict the possibility of the chemical recovery of this ecosystem. The benthic macroinvertebrate communities from both branches

Published by Copernicus Publications on behalf of the European Geosciences Union. 


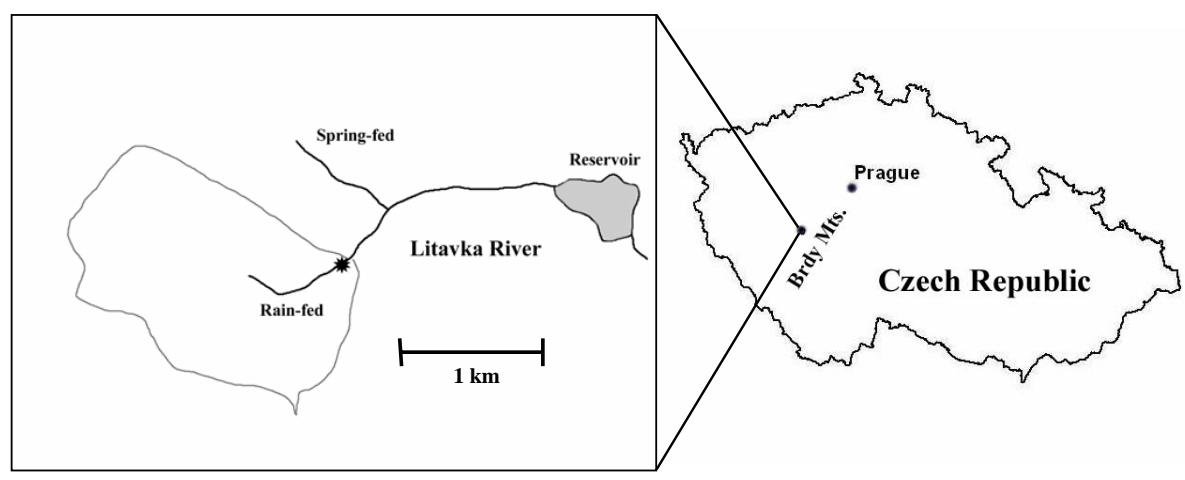

Fig. 1. Map of the Czech Republic, showing the location of the Brdy Mountains and the Litavka River. The rain-fed and spring-fed branches are indicated. The star indicates the location of regular monitoring of the rain-fed branch, and the catchment is outlined.

were studied, and the likelihood of colonization of species from the spring-fed branch to the rain-fed was evaluated considering the predicted extent of this chemical recovery.

Recently, the question has arisen of how predicted patterns of global climate change might affect the course of recovery in sensitive ecosystems such as the Litavka. "Confounding factors" (Wright and Jenkins, 2001) related to climate-related changes in temperature and precipitation are predicted to influence the outcome of surface water recovery. Some of these factors are changes in dissolved organic carbon (DOC) (Freeman et al., 2001; Evans et al., 2005), temperature related weathering (SommarugaWögrath et al., 1997), increased $\mathrm{NO}_{3}$ leaching at higher temperatures (Wright, 1998), and increased or more variable precipitation and runoff. Though levels of acid deposition typically drive acidification models, Wright et al. (2006) tested the sensitivity of MAGIC to temperature-related parameters, such as weathering, organic decomposition, uptake of base cations and nitrogen (through forest growth), precipitation, and production of organic acids through decomposition. They found that in inland forested sites, including two sites in the Czech Republic, increases in DOC, forest growth, and organic decomposition had particular relevance in affecting the future recovery of soil and water chemistry from acidification. Future air temperature calculated by a regional climate model was used to derive scenarios for changes in some of these factors up to the year 2100. We then incorporated these scenarios into the MAGIC model using forecast sequences using the methods described in Wright et al. (2006). Our aim was to examine how these climate-related changes might impact the course of future recovery of the ecosystem.

\section{Site description}

The Brdy Mountain region is one of the largest forested areas within the borders of the Czech Republic (Fig. 1). Many small streams originate in the uplands, most of which are heavily impacted by acidification (Horecký et al., 2006;
Veselý and Majer, 1996). The headwater of the Litavka River, in the south-west part of the mountains, is composed of two small branches in the first approximately two kilometres. One branch is rain-fed, while the other has its main source in a small spring. The rain-fed branch of the Litavka has a catchment lying at $695-843 \mathrm{~m}$ a.s.1. $\left(49^{\circ} 42^{\prime} 17^{\prime \prime} \mathrm{N}\right.$, $13^{\circ} 50^{\prime} 56^{\prime \prime} \mathrm{E}$; area $1.85 \mathrm{~km}^{2}$ ), and the adjacent spring-fed catchment is separated by just a small ridge. The bedrock of both branches is typical for most of the Brdy Mountains, and consists of Cambrian sandstone, conglomerates, and quartzites. Acidic poor brown cambisolic soils cover both catchments, and peat bogs occur in many areas. Much of the original forest in the area was composed of beech with occasional fir, but was replaced by spruce monocultures, most likely starting before the middle of the 19th century. The vegetation is currently dominated by Norway spruce (Picea abies) which covers approximately $90 \%$ of the catchments, most of which are 80-90 years old; occasionally beech ( $\mathrm{Fa}$ gus sp.) oak (Quercus sp.) and hazel (Corylus sp.) are found in upper parts. The median stream flow of the rain fed-branch is $1.01 \mathrm{~s}^{-1}$, though this fluctuates widely during the year depending on rainfall and snow cover, ranging from nonflowing to extreme flood events of over $12001 \mathrm{~s}^{-1}$. The flow rate of the spring-fed branch is similar, but has lower seasonal variation because of the underground source of much of the water. Thus, both catchments have almost identical characteristics and exposure to deposition, and differ primarily in the hydraulic regime of the streams. The two branches converge less than $1 \mathrm{~km}$ below the sampling sites, and then lead into a small reservoir (Fig. 1). At the beginning of the 19th century the streams supported brown trout (Salmo trutta Č́a, 1998). Currently, the reservoir supports a native population of minnow (Phoxinus phoxinus), though introduced perch (Perca fluviatilis) is having a large impact on its population (Fischer, 2005). The minnow, however, does not migrate to either branch. 


\section{Materials and methods}

\subsection{Biological sampling}

Samples of benthic macroinvertebrates were taken by "kick sampling" (Frost et al., 1971) with a hand net of mesh-size $500 \mu \mathrm{m}$ from 10 habitats for $30 \mathrm{~s}$ each, giving adequate attention to all microhabitats. This was supplemented by a $20-$ min picking of individuals off submerged stones and wood. Organisms were preserved in the field with $80 \%$ ethanol. Samples from the rain-fed branch were generally taken in monthly intervals from January 1999 to April 2000, and then again in September 2004; samples from both rain-fed and spring-fed branches were taken in April, July and October 2005.

\subsection{Water, precipitation, and soil chemistry}

Samples of water chemistry in the rain-fed branch were taken in at least monthly intervals from November 1998 through March 2000 (22 times). In 2001 sampling was performed every two weeks (27 times). Since 2001, water chemistry samples of the rain-fed branch were taken as follows: January and February 2002; September and November 2004; April, May, July, August and November 2005, and September 2006. Samples from the spring-fed branch were taken in April, July and October 2005, and in September 2006. Samples were filtered on-site through a $40 \mu \mathrm{m}$ polyamide filter, and transported cold to the laboratory for analysis. In 2001, detailed precipitation (bulk and throughfall) and soil chemistry were studied in the rain-fed branch catchment (Pehal, 2004). Three soil pits were sampled, chosen to best represent the range of soils in the catchment. Pits were dug down to bedrock, and separated into the different organic and mineral layers present at each site. Wet and dry weight, volume and chemical properties were analyzed for each of these layers. Outflow of the rain-fed branch was measured fortnightly in 2001 at a weir installed at the sampling site, approximately $1 \mathrm{~km}$ from the source.

For details on analytical methods, see Kopáček et al. (2004b) and Pehal (2004). In short: ions were determined by ion chromatography, total reactive aluminium $\left(\mathrm{Al}_{R}\right)$ according to Driscoll (1984), alkalinity by Gran titration, and total organic carbon (TOC) by Shimadzu TOC analyzer. Exchangeable base cations (SBC - sum of $\mathrm{Ca}^{2+}, \mathrm{Mg}^{2+}, \mathrm{Na}^{+}$, and $\mathrm{K}^{+}$) and exchangeable acidity (sum of $\mathrm{Al}^{3+}$ and $\mathrm{H}^{+}$) were determined at natural soil $\mathrm{pH}$ by extracting of air dried soil with $1 \mathrm{M} \mathrm{NH}_{4} \mathrm{Cl}$ and a $1 \mathrm{M} \mathrm{KCl}$ solution, respectively.

3.3 Modelling of the stream-fed branch: calibration and hindcast

The MAGIC model (version 7, Cosby et al., 2001) was used to reconstruct past stream and soil chemistry, and to predict their future trends. The model uses a lumped representation of catchment physical and chemical parameters. Required
Table 1. Morphological characteristics of the Litavka rain-fed branch, plus fixed and optimized parameters used in the MAGIC model. Measured fixed parameters are indicated by *.

\begin{tabular}{|c|c|c|}
\hline Location & \multicolumn{2}{|c|}{$49^{\circ} 42^{\prime} 17^{\prime \prime} \mathrm{N}, 13^{\circ} 50^{\prime} 56^{\prime \prime} \mathrm{E}$} \\
\hline Altitude (m a.s.1.) & \multicolumn{2}{|c|}{$695-843$} \\
\hline Catchment area $\left(\mathrm{km}^{2}\right)$ & \multicolumn{2}{|c|}{1.85} \\
\hline Tree species, coverage & \multicolumn{2}{|c|}{$\begin{array}{l}\text { Norway spruce (Picea abies), } \\
90 \% \text { of catchment }\end{array}$} \\
\hline Bedrock & \multicolumn{2}{|c|}{$\begin{array}{l}\text { Cambrian conglomerate, } \\
\text { sandstone, quartzite }\end{array}$} \\
\hline Soil & \multicolumn{2}{|c|}{ Cambisol } \\
\hline Precipitation volume & \multicolumn{2}{|c|}{$640 \mathrm{~mm} / \mathrm{yr}$} \\
\hline Discharge & \multicolumn{2}{|c|}{$260 \mathrm{~mm} / \mathrm{yr}$ (estimated - see text) } \\
\hline & Soil & Stream \\
\hline \multicolumn{3}{|c|}{ Fixed Parameters (measured* or estimated) } \\
\hline Soil depth (m) & $0.78 *$ & \\
\hline Porosity $(\%)$ & 50 & \\
\hline Bulk density $\left(\mathrm{kg} / \mathrm{m}^{3}\right)$ & $535^{*}$ & \\
\hline Cation exchange capacity (meq/kg) & $126^{*}$ & \\
\hline SO4 half-saturation $\left(\mathrm{meq} / \mathrm{m}^{3}\right)$ & 500 & \\
\hline SO4 max-capacity (meq/kg) & 12 & \\
\hline Ca saturation in $2001(\%)$ & $1.7^{*}$ & \\
\hline Mg saturation in $2001(\%)$ & $0.8^{*}$ & \\
\hline Na saturation in $2001(\%)$ & $0.2^{*}$ & \\
\hline K saturation in $2001(\%)$ & $3.4^{*}$ & \\
\hline Total base saturation in $2001(\%)$ & $6.1^{*}$ & \\
\hline Total organic acid $\left(\mathrm{mmol} / \mathrm{m}^{3}\right)$ & 100 & $12.4^{*}$ \\
\hline Temperature $\left({ }^{\circ} \mathrm{C}\right)$ & 5.0 & $6.6^{*}$ \\
\hline $\mathrm{pCO}_{2}(\mathrm{~atm})$ & 0.0045 & 0.0005 \\
\hline $\mathrm{pK}_{1}$ of organic acids $(-\log )$ & 2.64 & 2.64 \\
\hline $\mathrm{pK}_{2}$ of organic acids $(-\log )$ & 5.66 & 5.66 \\
\hline $\mathrm{pK}_{3}$ of organic acids $(-\log )$ & 5.94 & 5.94 \\
\hline \multicolumn{3}{|l|}{ Optimized parameters } \\
\hline $\mathrm{Al}\left(\mathrm{OH}_{3}\right)$ solubility constant $(\mathrm{Log})$ & 7.7 & 8.0 \\
\hline Weathering of $\mathrm{Ca}\left(\mathrm{meq} / \mathrm{m}^{2}\right)$ & 3.2 & \\
\hline Weathering of $\mathrm{Mg}\left(\mathrm{meq} / \mathrm{m}^{2}\right)$ & 18.0 & \\
\hline Weathering of $\mathrm{Na}\left(\mathrm{meq} / \mathrm{m}^{2}\right)$ & 0.0 & \\
\hline Weathering of $\mathrm{K}\left(\mathrm{meq} / \mathrm{m}^{2}\right)$ & 4.0 & \\
\hline Uptake of $\mathrm{Ca}\left(\mathrm{meq} / \mathrm{m}^{2}\right)$ & 8.0 & \\
\hline Uptake of $\mathrm{Mg}\left(\mathrm{meq} / \mathrm{m}^{2}\right)$ & 4.0 & \\
\hline Uptake of $\mathrm{Na}\left(\mathrm{meq} / \mathrm{m}^{2}\right)$ & 0.1 & \\
\hline Uptake of $\mathrm{K}\left(\mathrm{meq} / \mathrm{m}^{2}\right)$ & 7.2 & \\
\hline Selectivity coefficient Al-Ca (Log) & 0.399 & \\
\hline Selectivity coefficient Al-Mg ( $\mathrm{Log})$ & 1.170 & \\
\hline Selectivity coefficient Al-Na (Log) & -0.798 & \\
\hline Selectivity coefficient Al-K (Log) & -5.691 & \\
\hline
\end{tabular}

inputs to the model are historical sequences of deposition chemistry, soil and stream water chemistry for a reference year, and water fluxes in the catchment. For the catchment of the Litavka rain-fed branch, the model was calibrated for the reference year 2001 as follows:

1. Historical deposition curves of ions were taken from those used by Kopáček et al. (2001) for the nearby Bohemian Forest. These deposition sequences have been successfully used to apply the MAGIC model to three lakes in the region (Majer et al., 2003), and well represent the large changes in deposition of $\mathrm{S}$ and $\mathrm{N}$ that have occurred in central Europe in the past few decades. 

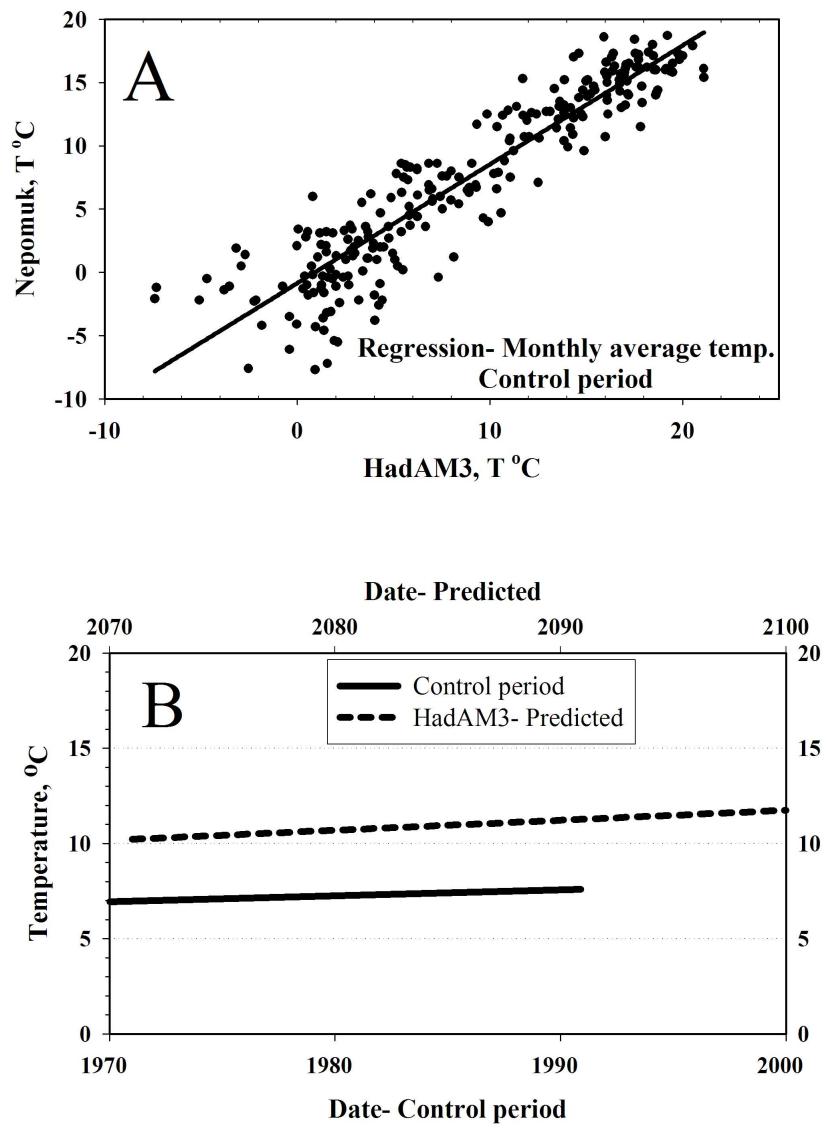

Fig. 2. Comparison of data from the Nepomuk meteorological station and predicted by the HadAM $3 \mathrm{H}$ regional climate model. (A) Regression of monthly average temperature $\left({ }^{\circ} \mathrm{C}\right)$ from the control period 1970-1990 of Nepomuk data versus data predicted by HadAM3 (y=0.9388x $-0.8527, R^{2}=0.8559$ ). (B) Trends of monthly temperature for measured data from the Nepomuk station (controllower $\mathrm{x}$-axis, solid line) and predicted by the HadAM3 model (predicted- upper $\mathrm{x}$-axis, dashed line). Average measured temperature from $1970-1990$ is $7.3^{\circ} \mathrm{C}$, and predicted for $2071-2100$ is $11.0^{\circ} \mathrm{C}$

2. Soil data from the sampled pits was weighted according to the approximate area of the catchment represented by each of the pits, resulting in catchment-weighted means of all soil chemical parameters (Table 1). Fixed parameters of $\mathrm{SO}_{4}$ maximum absorption capacity and halfsaturation constant, organic acid dissociation constants, and $\mathrm{Al}\left(\mathrm{OH}_{3}\right)$ solubility for both soil and stream were estimated using published values from other similar acidified sites in the Czech Republic (Majer et al., 2003; Hruška and Krám, 2003) (Table 1). The $\mathrm{SO}_{4}$ maximum absorption capacity was adjusted during the calibration procedure to match observed values of stream sulphate levels. $\mathrm{Al}\left(\mathrm{OH}_{3}\right)$ solubility was adjusted to match observed stream $\mathrm{pH}$ and $\mathrm{Al}$ concentrations in the reference year. Uptake of $\mathrm{NH}_{4}$ and $\mathrm{NO}_{3}$ by biomass was set in the model as sinks, so that concentrations calculated by the model equalled measured stream concentrations in the reference year.

3. Precipitation data for 2001 was applied by weighting throughfall and bulk fluxes of measured ions according to the proportion of the catchment covered by trees $(90 \%)$ or open areas. Outflow measured in discreet intervals from the weir $(179 \mathrm{~mm} / \mathrm{year}, 28 \%$ of precipitation volume) was too low to adequately balance chloride $(\mathrm{Cl})$ in the model, which should act conservatively in the catchment (so that stream $\mathrm{Cl}$ flux at a given time should be equal to precipitation $\mathrm{Cl}$ flux). This is likely due to the missing of significant outflow volume during flooding events. Therefore, outflow was increased to $40 \%$ of measured precipitation based on hydrological conditions for a similar catchment (Hruška and Krám, 2003) and by calibration of $\mathrm{Cl}$ in the model.

4. Weathering rates, base cation-exchange selectivity coefficients, and initial base saturation (BS) were optimized by a trial-and-error procedure until modelled pools and concentrations equalled measured pools and concentrations in the calibration year.

Fixed and optimized parameters used as inputs to MAGIC are given in Table 1 . The model was run using a yearly time step, starting in 1860 . Though chemical data at shorter time intervals was available, because of the changes in sampling frequency and low seasonal variability observed, yearly averages were used in the MAGIC calibration. Since the aim of this modelling was to create a base recovery scenario against which climate-related scenarios could be tested (see below), uncertainty analysis in the model was not performed.

\subsection{Model forecasting}

Forecasting of future trends in soil and stream chemistry was done in two steps. First, deposition trends used in the Bohemian Forest (Majer et al., 2003) were applied until 2050, reflecting emissions levels required under the Gothenburg Protocol. Since the Czech Republic already meets the Protocol's target emissions for $\mathrm{SO}_{4}^{2-}$ and $\mathrm{NO}_{3}^{-}$compounds, only slight further decreases are expected, while slight increases in $\mathrm{NH}_{4}^{+}$are predicted.

Next, a regional scale climate model was used to estimate future changes in temperature and precipitation in order to develop longer time-frame trends. The PRUDENCE project (Prediction of regional scenarios and Uncertainties for Defining EuropeaN Climate change risks and Effects, http://prudence.dmi.dk/) has run a number of experiments with regional climate models covering most of Europe at a resolution of $50 \times 50 \mathrm{~km}$. Control runs covering the period from 1961-1990 allow users to compare and calibrate the model datasets to known measured local data. Future scenario runs, covering 2071-2100, are available using different 
assumptions in changes of atmospheric carbon dioxide levels. Among the available data output are air temperature, precipitation, cloud cover, runoff, humidity, and wind speed. Monthly data was downloaded for the $50-50 \mathrm{~km}$ grid covering the Litavka catchments from the PRUDENCE website. The dataset chosen was from the RCAO regional climate model, which uses driving data from the HadAM3H global circulation model. The A2 emissions scenario from the Intergovernmental Panel on Climate Change was used to provide the regional model with future emissions levels. This scenario represents an almost "worst-case" steady increase in $\mathrm{CO}_{2}$ levels. For more information and details on these climate models, see the Prudence website (above).

Air temperatures and monthly precipitation volumes for the "control period" of the model (1960-1990) were compared to actual data collected by the Czech Hydrometerological Institute at the nearby Nepomuk meteorological station (approx. $30 \mathrm{~km}$ from the sampling sites) for the period from 1970-1990. The control model temperature and the observed data were well correlated (Fig. $2, R^{2}=0.86$ ). Thus, average temperatures were calculated for the control period and for the future period 2071-2100. The difference in these two averages $\left(+4^{\circ} \mathrm{C}\right.$ for the A2 scenario, Fig. 2) was then added to the measured temperature at the Nepomuk site to derive an estimate of the site average temperature for the future period. This "delta change" method assumes that the future change in temperature over time at the site will be the same as that for the grid square as a whole. Since the MAGIC model was run in yearly time steps, spatial differences in average temperatures between the site and the grid square were assumed to be negligible. Monthly average precipitation generated by the climate model was poorly correlated with the observed data $\left(R^{2}=0.003\right)$. In addition, the climate model predicts no significant change in precipitation for the period 2071-2100 compared to the period 1970-1990 (data not shown). Therefore, water fluxes in the catchment were assumed to be constant in the MAGIC forecasts.

The predicted $4^{\circ} \mathrm{C}$ increase in temperature was incorporated into the MAGIC model by estimating changes as follows:

1. Weathering of base cations was estimated to increase by $5 \%$ for every $1{ }^{\circ} \mathrm{C}$ increase in temperature. Therefore, present weathering rates were increased steadily in the model until they reached $20 \%$ higher rates in the year 2085 (the middle of the 30-year climate-modelled period) and then held constant until 2100 (Wright et al., 2006; Sommaruga-Wögrath et al., 1997).

2. Experimental results (Tipping et al., 1999; Freeman et al., 2001) have shown that DOC release from soils can increase in warmer conditions. The latter study found that a $10^{\circ} \mathrm{C}$ warming of peaty soils in the UK resulted in a 33\% increase in dissolved organic carbon release from the soils. This was used to estimate a steady increase in
Table 2. Average chemical parameters of stream water in 2005 and 2006 of both branches of the Litavka River. $n=$ number of measurements.

\begin{tabular}{|c|c|c|c|}
\hline Parameter & Units & $\begin{array}{c}\text { Rain-fed } \\
\text { branch, } n=6\end{array}$ & $\begin{array}{c}\text { Spring-fed } \\
\text { branch, } n=4\end{array}$ \\
\hline $\mathrm{pH}$ & & 4.13 & 5.61 \\
\hline Gran alkalinity & $\mu$ eq $1^{-1}$ & -65 & 9 \\
\hline Reactive Al & $\mu \mathrm{moll}^{-1}$ & 65 & 2 \\
\hline $\mathrm{Ca}^{2+}$ & $\mu \mathrm{eq} 1^{-1}$ & 47 & 129 \\
\hline $\mathrm{Mg}^{2+}$ & $\mu$ eq $1^{-1}$ & 64 & 174 \\
\hline $\mathrm{Na}^{+}$ & $\mu$ eq $1^{-1}$ & 42 & 66 \\
\hline $\mathrm{K}^{+}$ & $\mu$ eq $1^{-1}$ & 17 & 24 \\
\hline $\mathrm{NH}_{4}^{+}$ & $\mu$ eq $1^{-1}$ & 1 & 4 \\
\hline SBC & $\mu$ eq $1^{-1}$ & 170 & 393 \\
\hline $\mathrm{SO}_{4}^{2-}$ & $\mu$ eq $1^{-1}$ & 386 & 303 \\
\hline $\mathrm{NO}_{3}^{-}$ & $\mu$ eq $1^{-1}$ & 6 & 49 \\
\hline $\mathrm{Cl}^{-}$ & $\mu$ eq $1^{-1}$ & 35 & 36 \\
\hline $\mathrm{F}^{-}$ & $\mu \mathrm{eq} 1^{-1}$ & 7 & 2 \\
\hline TOC & $\operatorname{mgC} 1^{-1}$ & 4.50 & 2.76 \\
\hline
\end{tabular}

DOC release, reaching $15 \%$ higher than present values in 2085, and then held constant until 2100.

3. In an artificial experiment raising soil temperature and measuring changes in nitrogen output from soils (CLIMEX, van Breeman et al., 1998), a $3.7^{\circ} \mathrm{C}$ increase in air temperature resulted in an approximate doubling in net soil $\mathrm{N}$ mineralization. A study by Hart and Perry (1999) found that transfer of soil from a high-elevation site to a site with mean annual air temperature $3.9^{\circ} \mathrm{C}$ higher resulted in a more than doubling of annual soil net $\mathrm{N}$ mineralization and nitrification. To approximate such an increase and subsequent $\mathrm{NO}_{3}$ leaching, we increased the soil source of $\mathrm{NO}_{3}$ steadily, so that present values were doubled by 2085 and then held constant until 2100 .

4. Increased temperature could lead to increased forest productivity and growth (e.g. Proe et al., 1996). Modelling of a boreal forest by Kellomäki and Väisänen (1997) indicated that temperature increase of $4^{\circ} \mathrm{C}$ over a 100 -year period combined with increased $\mathrm{CO}_{2}$ could lead to a $32-40 \%$ increase in photosynthesis and subsequent stemwood growth. To reflect this possible growth of plants in response to higher temperatures and expected occasional forest harvesting, the uptake of base cations and nitrogen was steadily increased to reach 50\% higher values in 2085 and then held constant until 2100.

Each of these possible changes was incorporated in the MAGIC model separately, and then combined to estimate an 

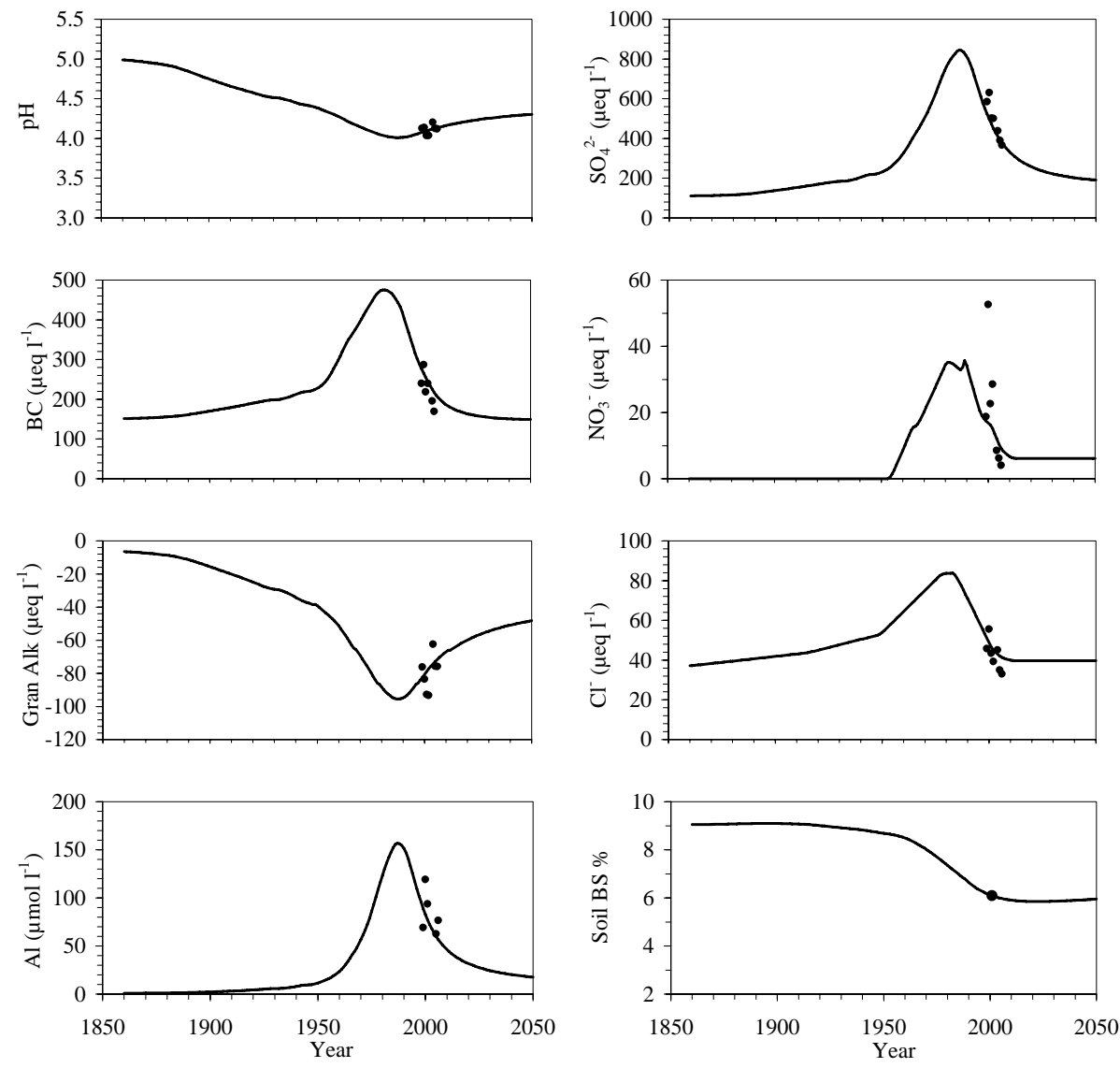

Fig. 3. Results of MAGIC modelling from 1860 to 2050. Solid line- modelled data, solid circles- yearly averages of measured data. All data is for stream chemistry, except base saturation for soil. All units in $\mu$ eq $1^{-1}$, except $\mathrm{Al}\left(\mu \mathrm{mol} 1^{-1}\right)$ and base saturation (BS-\%).

overall impact of these factors on soil and water chemistry up to 2100 .

\section{Results}

\subsection{Chemistry of rain-fed and spring-fed branches}

Representative recent chemistry of the rain-fed and springfed branches of the Litavka River is given in Table 2. In 2005/2006, pH of the rain-fed branch averaged 4.13 (min 4.07, max 4.24). This is similar to the average covering the entire sampling period (1998-2006) of 4.09 (min 3.96, $\max 4.27$ ). The $2005 / 2006$ average $\mathrm{pH}$ in the spring-fed branch was 5.61 (minimum 5.08, maximum 6.03). Stream $\mathrm{SO}_{4}$ concentrations were similar in the two branches (averaging 386 and $303 \mu \mathrm{eq} 1^{-1}$ in the rain-fed and spring-fed branch, respectively). The branches differed significantly, however, in base cation concentrations, which were much lower in the rain-fed branch than in the spring-fed (average SBCs of 170 and $364 \mu \mathrm{eq} 1^{-1}$, respectively). The alkalinity of the two branches differs accordingly, with negative measured Gran alkalinity (average $-65 \mu$ eq $1^{-1}$ ) in the more acidified rain-fed branch, and slightly positive values (average $9 \mu \mathrm{eq}^{-1}$ ) in the spring-fed. $\mathrm{NO}_{3}$ concentrations are almost an order-of-magnitude lower in the rain-fed than spring-fed branch (averages of 6 and $49 \mu \mathrm{eq} \mathrm{l}^{-1}$, respectively). Values of $\mathrm{Al}_{R}$ are still currently extremely high in the rain-fed branch and very low in the spring-fed, with averages of 65 and $2 \mu \mathrm{moll}^{-1}$, respectively. Levels of organic carbon are low in both branches- the average total organic carbon (TOC) is $4.5 \mathrm{mg}$ and $2.8 \mathrm{mg} \mathrm{Cl}^{-1}$ in the in the rainfed and spring-fed, respectively. Because of low amounts of particulate matter in these streams, TOC is a good estimation of dissolved organic carbon (DOC, Horecký et al., 2006).

\subsection{Benthic community of the branches}

Parallel to the difference in acidification status, the population structures of benthic macroinvertebrates was found to differ significantly. The benthic community of the strongly acidified Litavka rain-fed branch is dominated by the stoneflies Leuctra nigra, Nemurella pictetii and chironomids Micropsectra spp., Tanytarsus spp. (Chironominae), Corynoneura cf. lobata (Orthocladiinae). Less abundant, but characteristic for the community were larvae of the caddisfly 
Table 3. Benthic macroinvertebrates of the Litavka rain-fed and spring-fed branches. The top of the table illustrates taxa differing between the two branches and the bottom lists taxa common to both branches. Bold indicates overall relative abundance higher than $1 \%$ and underlined higher than $10 \%$; *Amphinemura sulcicollis has higher than $1 \%$ abundance in the rain-fed branch.

\begin{tabular}{|c|c|c|c|}
\hline & & Litavka rain-fed branch & Litavka spring-fed branch \\
\hline \multirow{10}{*}{ 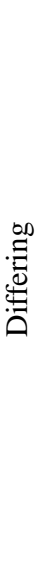 } & Turbellaria & Dendrocoelum sp. & - \\
\hline & Mollusca & - & Pisidium casertanum \\
\hline & Plecoptera & Nemoura cambrica & Diura bicaudata, Leuctra pseudocingulata \\
\hline & Ephemeroptera & - & Leptophlebia marginata \\
\hline & Odonata & Aeshna sp. juv. & Cordulegaster sp. juv. \\
\hline & Megaloptera & Sialis fuliginosa & - \\
\hline & Trichoptera & $\begin{array}{l}\text { Limnephilus coenosus, Micropterna nycterobia, } \\
\text { M. lateralis }\end{array}$ & $\begin{array}{l}\text { Drusus annulatus, Potamophylax nigricornis, } \\
\text { Chaetopteryx villosa, Sericostoma personatum, } \\
\text { Rhyacophila praemorsa/polonica, Oxyethira sp., } \\
\text { Crunoecia irrorata, Adicella fillicornis }\end{array}$ \\
\hline & Heteroptera & Gerris lacustris, Notonecta glauca & \\
\hline & Diptera & Euphylidorea sp., Wiedemannia sp. & $\begin{array}{l}\text { Dicranota sp., Scleroprocta sp., Eloeophila sp., Di- } \\
\text { amesa } \mathrm{sp} .\end{array}$ \\
\hline & Coleoptera & $\begin{array}{l}\text { Agabus bipustulatus, Deronectes platynotus, Hy- } \\
\text { droporus ferrugineus }\end{array}$ & \\
\hline \multirow{5}{*}{ ¿̊̃ } & Plecoptera & \multicolumn{2}{|c|}{ Leuctra nigra, Amphinemura sulcicollis*, Nemurella pictetii, Protonemura auberti } \\
\hline & Trichoptera & \multicolumn{2}{|c|}{$\overline{P l e c t r o c n e m i a ~ c o n s p e r s a}$} \\
\hline & Heteroptera & \multirow{2}{*}{\multicolumn{2}{|c|}{$\begin{array}{l}\text { Velia caprai } \\
\text { Pedicia (P.) rivosa, Ceratopogonidae g. sp., Chelifera sp., Simulium spp., Tanypodinae g. sp., } \\
\text { Orthocladiinae g. sp., Chironominae g. sp. }\end{array}$}} \\
\hline & Diptera & & \\
\hline & Coleoptera & \multicolumn{2}{|c|}{ Agabus guttatus, Agabus spp. juv., Anacaena globulus, Helophorus flavipes } \\
\hline
\end{tabular}

Plectrocnemia conspersa, the alderfly Sialis fuliginosa, the stonefly Protonemura auberti, the chironomid Macropelopia sp. (Tanypodinae), the black fly Simulium spp., and the water beetle Agabus spp. (Table 3).

Besides the taxa present in both branches (listed at bottom of Table 3), common solely in the moderately acidified Litavka spring-fed branch are the caddisflies Drusus annulatus and juveniles of the family Limnephilidae (Potamophylax spp. and Chaetopteryx spp.), the stonefly Diura bicaudata, and dipteran genera Dicranota and Eloeophila. Moreover, several individuals of the mollusc Pisidium casertanum, the mayfly Leptophlebia marginata, and the caddisflies Rhyacophila praemorsa/polonica and Sericostoma personatum were found. In addition, there were marked differences in the relative abundances of Corynoneura sp. (lower) and Amphinemura sulcicollis (higher).

\subsection{MAGIC modelling: rain-fed branch}

Modelled trends in $\mathrm{SO}_{4}$ and SBCs well-reflected their observed concentration in stream water of the rain-fed branch (Fig. 3). $\mathrm{SO}_{4}$ in 1860 was $96 \mu$ eq $1^{-1}$, reflecting the original background level of $\mathrm{SO}_{4}$ in this region. A historical measurement in 1892 of the similar Lysina stream showed $\mathrm{SO}_{4}$ of $77 \mu \mathrm{eq} 1^{-1}$ (Hanaman, 1896; estimated as equivalent to $53 \mu \mathrm{eq} \mathrm{l}^{-1}$ using current analytical methods by Hruška et al.,
2002). Levels increased sharply beginning in the 1950s to a peak of $650 \mu \mathrm{eq} 1^{-1}$ in the late 1980s, followed by a sharp drop to current concentrations below $400 \mu \mathrm{eq}^{-1}$. However, even though precipitation concentrations of $\mathrm{SO}_{4}$ are already under $40 \mu \mathrm{eq}^{-1}$, levels in the stream are predicted to only have declined to $190 \mu \mathrm{eq} 1^{-1}$ by 2050 . Modelled SBCs in stream water was $124 \mu$ eq $1^{-1}$ in 1860 , increased to $370 \mu \mathrm{eq} 1^{-1}$ in 1990 , and since have declined to the present $<200 \mu \mathrm{eq} \mathrm{l}^{-1}$. Modelled values in 2050 will be approximately equivalent to values before the industrial age.

Historic and present $\mathrm{pH}$ reflects the large impact of mainly $\mathrm{SO}_{4}$ deposition in the catchment. In 1860 , modelled $\mathrm{pH}$ was 5.0 and steadily decreased to a minimum of 4.05 in 1988 (Fig. 3). Measured yearly average values since 1999 range from 4.04 to 4.20 , and the model reflects this slight increase. A continued slight increase up to 2050 will result in stream $\mathrm{pH}$ of around 4.3, still more than a half $\mathrm{pH}$ unit lower than values in 1860 . Modelled Gran alkalinity was already below zero in 1860, and dropped rapidly starting in the 1950s to a minimum of $-95 \mu \mathrm{eq} \mathrm{l}^{-1}$ during the $1990 \mathrm{~s}$. Alkalinity will gradually increase, but only to about $-50 \mu \mathrm{eq} 1^{-1}$ by 2050 .

Low water $\mathrm{pH}$ has resulted in extremely high observed $\mathrm{Al}_{R}$ concentrations in the stream, with values over $100 \mu \mathrm{moll}^{-1}$ consistently measured in 2000 and 2001 and currently averaging $65 \mu \mathrm{moll}^{-1}$. These values were successfully reproduced by the model (Fig. 3). During the peak of 

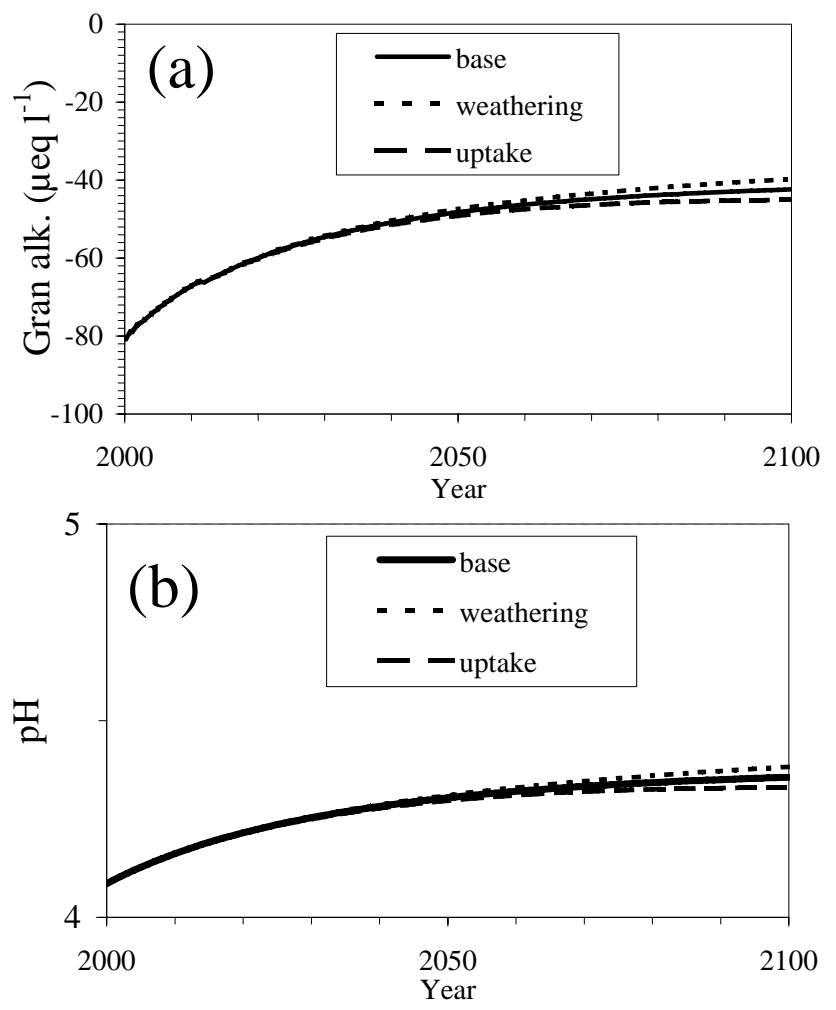

Fig. 4. Predicted $\mathrm{pH}$ (a) and Gran alkalinity (b) in streamwater from temperature-related scenarios up to 2100 . Solid line- base recovery case; predicted values based on recovery from acidification alone. Short dashed line- values predicted by a $20 \%$ increase in weathering. Long-dashed line- values predicted by a $50 \%$ increase in uptake of base cations and nitrate (forest growth). Values predicted by increased DOC and $\mathrm{N}$ mineralization were intermediary, and not shown.

acidification in 1988, modelled values of total Al reached over $150 \mu \mathrm{moll}^{-1}$. Because of low levels of DOC and low $\mathrm{pH}$, almost all $\mathrm{Al}$ in the model is in the ionic form. This is substantially higher than has been observed in other acidified catchments in the region; for instance Hruška and Krám (2003) found peak values of around $90 \mu \mathrm{moll}^{-1}$ of total $\mathrm{Al}$ in a stream with $\mathrm{pH}$ around 3.9.

Soil base saturation (BS) was modelled at already very low values of $9 \%$ in 1860 (with soil $\mathrm{pH}$ of 4.2) indicating that the Litavka soils already had a low BS before the onset of widespread acidification in the region. Modelled BS steadily declined to the measured value of $6.1 \%$ in 2001. BS is predicted to continue declining slightly to about $5.9 \%$, and even after 40 years of lower atmospheric acid deposition, there is no predicted significant increase expected.

\subsection{Climate models}

The results of extending the MAGIC model to the year 2100 by including possible effects of a $4^{\circ} \mathrm{C}$ temperature in- crease are shown in Fig. 4. Interestingly, the effects on $\mathrm{pH}$ and alkalinity are minimal. Taken individually, the effects of increased weathering, DOC release, $\mathrm{NO}_{3}$ mineralization, and uptake of nutrients (forest growth) resulted in changes to stream $\mathrm{pH}$ of less than $2 \%$ (i.e. the highest predicted $\mathrm{pH}$ of 4.38 in 2100 resulting from increased weathering vs. the lowest predicted $\mathrm{pH}$ of 4.33 from increased uptake). While the effects on Gran alkalinity differed by approximately $13 \%$ (the highest of $-39 \mu \mathrm{eq} 1^{-1}$ resulting from increased weathering vs. the lowest $-45 \mu \mathrm{eq} \mathrm{l}^{-1}$ from increased uptake), these changes are minor when compared to the large increase in alkalinity caused by recovery from acidification alone (base recovery, Fig. 4) (from $-80 \mu \mathrm{eq} 1^{-1}$ in 2001 to $-48 \mu \mathrm{eq} 1^{-1}$ in 2050 , predicted to increase to $-42 \mu \mathrm{eq} \mathrm{l}^{-1}$ in 2100 without any temperature-related effects). Because some of the effects have negative impacts compared to the base recovery and some positive, when combined, the changes to $\mathrm{pH}$ and alkalinity under the scenarios is negligible. The impact on soil BS, however, is more marked (Fig. 5). Of the tested scenarios, only increased weathering had a positive impact, increasing BS from the base recovery of $6.2 \%$ in 2100 to $6.6 \%$. All other scenarios decreased BS, with increased uptake having the greatest negative impact, decreasing predicted BS in 2100 to 5.6\%. The combined effect of the scenarios was an overall decrease in BS to about $5.8 \%$.

\section{Discussion}

Modelling of the rain-fed branch of the Litavka shows that the reversibility from long-term extreme acidification will be gradual and slow. Even though atmospheric deposition has been substantially reduced, the effects of high historical deposition of $\mathrm{SO}_{4}$ to the catchment will continue to effect stream chemistry for decades in the future. This situation has been predicted for other acid-sensitive catchments in the Czech Republic, such as Lysina (Hruška and Krám, 2003) and in the Bohemian Forest (Majer et al., 2003). Similarly to the Litavka catchments, both of these regions lie on acid sensitive bedrock and have catchment vegetation dominated by spruce, which contribute to the acidification of surface waters. Desorption of soil $\mathrm{SO}_{4}$ and mineralization of $\mathrm{S}$ from organic compounds (Novák et al., 2000) create a hysteresis in the response of these catchments to reduced atmospheric inputs (Kopáček et al., 2002). In these catchments, however, present levels of $\mathrm{SO}_{4}$ in stream or lake water have already decreased to $<100 \mu \mathrm{eq}^{-1}$. According to the modelling, this situation is not expected in the Litavka rain-fed branch even by 2100 . These high concentrations are typical for streams in the region; Horecký et al. (2002) found $\mathrm{SO}_{4}$ levels ranging from $17.6 \mathrm{mg} \mathrm{l}^{-1}$ to $24.7 \mathrm{mg} \mathrm{l}^{-1}\left(370-510 \mu \mathrm{eq} \mathrm{l}^{-1}\right.$ ) in a survey of 8 streams throughout the Brdy Mountains. This reflects the relatively uniform long-term exposure of the region to high deposition levels. This region has historically 
been one of the most intensively industrialized areas of the country. In the 1990 s, surface water $\mathrm{SO}_{4}$ levels were as high as in the "black triangle" region of the former border between Czechoslovakia, East Germany, and Poland (Kreček and Hořická, 2001)

The catchments of both the rain-fed and spring-fed branches have a long history of anthropogenic influence. A large windstorm in 1749 extensively damaged forests in the region, and a glass works was built within a couple kilometres of the catchments, operating almost continuously for 34 years (Čáka, 1998). This was followed by construction of a reservoir about $2 \mathrm{~km}$ below the convergence of the two branches, which was finished in 1822 . The forest at this time was likely modified extensively, with most of the original deciduous forest removed and replaced by spruce plantations. This would have led to the intensification of acidification through increased dry deposition and removal of base cations through forest harvesting. This early and extensive removal of base cations from the catchment could explain the low BS modelled already in 1860 . Though the spring-fed branch has been exposed to practically identical historical deposition, and has similar catchment vegetation, soil, and bedrock, it is only moderately acidified. $\mathrm{SO}_{4}$ levels are almost as high as in the rain-fed branch, but base cations are more than double (Table 2). According to available geologic maps of the region (Czech Geologic Survey, http://nts5.cgu.cz, there is no difference in bedrock that could explain this difference. Presumably, then, this is related to the underground source of much of the water from the spring. We hypothesize that water in the spring-fed catchment has a longer residence time than in the rain-fed. This intra-catchment cycling would lead to increased biogeochemical weathering and increased base cations able to buffer the high $\mathrm{SO}_{4}$ concentrations, leading to higher $\mathrm{pH}$ and alkalinity. However, we cannot rule out the presence of differing geological formations contributing to the observed differences in chemistry.

The possible changes to stream $\mathrm{pH}$ and alkalinity due to climate warming will most likely be overshadowed by the continued high levels of $\mathrm{SO}_{4}$ releasing from catchment soils. However, climate-induced effects could have a significant impact on the catchment's ability to recover if deposition of acidifying compounds should change. Continued recovery relies on continued low atmospheric deposition of $\mathrm{S}$ and $\mathrm{N}$, and an increase in either of these could lead to a stop or reversal in chemical recovery. The effects of higher temperature on soil BS could have important impacts on the ability of the soil to buffer any increase in incoming acid. Also, these climate perturbations ignore other possible consequences of climate change that could have more significant impacts on catchment chemistry. For instance, a warmer climate could change the forest composition, increasing the proportion of deciduous trees. This would affect dry deposition of acidifying compounds during winter, as well as base cation fluxes in the soil due to changes in root depth (Puhe and Ulrich, 2001). In addition, nearby forests have
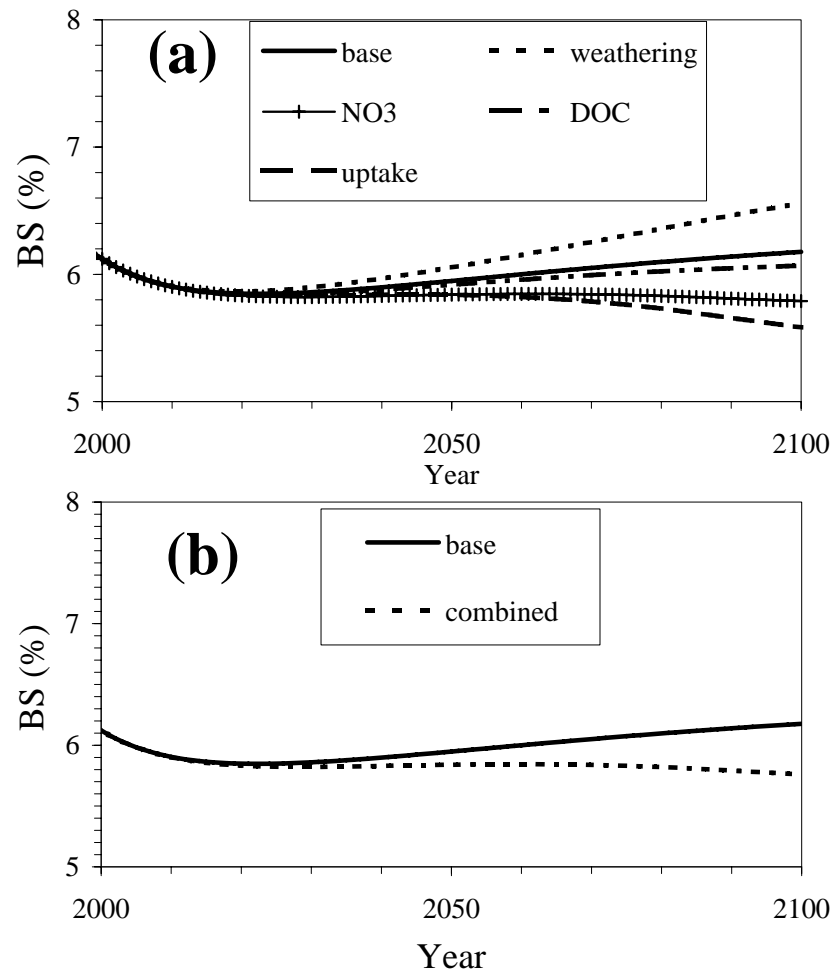

Fig. 5. Predicted soil base saturation from temperature-related scenarios up to 2100. (a) Values predicted for the base recovery case resulting from recovery from acidification alone (solid line), and results from individual scenarios. (b) Values predicted for the base recovery case (solid line), and predicted values from the combined effect of the tested scenarios (short dashed line).

been severely affected by bark-beetle (Ips typographus) infestations, and warmer weather could increase the sensitivity of the Litavka catchments to infection. The resulting large scale death or harvesting of trees would have significant impacts on catchment chemistry.

A decrease in species diversity in acidified streams is a well-documented effect of acid atmospheric deposition. Aquatic organisms are influenced by the toxicity of $\mathrm{H}^{+}$ions or ionic toxic metals (especially $\mathrm{Al}$ ), problems with ion regulation, corrosion of calcium from shells, changes in food availability, etc. (e.g. Økland and Økland, 1986; Herrmann et al., 1993). Several mechanisms can ameliorate some of the above-mentioned negative effects - e.g. higher humic or calcium content in the water (e.g. Havas and Rosseland, 1995) - but low TOC levels in both Litavka branches provide little protection against $\mathrm{Al}$ toxicity. Also, continued high $\mathrm{SO}_{4}$ levels will result in elevated $\mathrm{Al}$ concentrations in the rainfed branch for the next several decades, despite the large decreases in $\mathrm{SO}_{4}$ deposition.

In addition, there is an important difference in species' (and thus also community) tolerance to temporary (episodic) changes in water $\mathrm{pH}$ and chronic acidification. The Litavka 
rain-fed branch is currently strongly acidified and buffered by Al ions (Stumm and Morgan, 1981); therefore only little fluctuations in water $\mathrm{pH}$ occur (observed $\mathrm{pH}$ minimum during several flood events from 1998-2002 was 3.96, whereas maximum during extremely low flows in May 1999 was 4.27). The forecasted increase in $\mathrm{pH}$ and decline in $\mathrm{Al}$ concentration will likely result in a more pronounced difference in base-flow and high-flow (acid) episodes which can inhibit the process of recovery of the benthic community (Lepori et al., 2003). Most benthic macroinvertebrates occurring in this chronically acidified branch belong to acid resistant larvae of stoneflies, caddisflies, dipterans, and beetles (according to Braukmann, 2001; similarly in Hämäläinen and Huttunen, 1996) and the community structure is similar to other acidified headwater forest streams in Europe (e.g. Townsend et al., 1983).

Due to the heavy use of the surrounding area and deforestation of the study catchment before 1860 , this start of the modelled period does not represent the real background conditions of the rain-fed branch before anthropogenic influence. The overall similarity of both studied catchments (including bedrock) and streams (differing in hydraulic regime, but with comparable average flow rates) leads us to the opinion that the spring-fed branch, though not entirely unaffected by acidification, represents a good approximation of reference conditions for the rain-fed. Acid resistant taxa occurring in the Litavka spring-fed branch (classified as periodically critically acidic) and in less acid neighbouring streams can be considered potential sources of organisms during recovery of the rain-fed branch.

In general, most freshwater crustaceans, molluscs and mayflies are considered acid sensitive. The only mayfly present in the spring-fed branch, Leptophlebia marginata, is generally considered to be one of the most acid tolerant (e.g. Fjellheim and Raddum, 1990) and according to Engblom and Lingdell (1984) is able to survive at pH 4.2. However, it was not found in regional strongly acidified low-humic streams ( $\mathrm{pH}<4.6, \mathrm{TOC}<8.9 \mathrm{mg} \mathrm{l}^{-1}$; Horecký et al., 2006) although it was present in local streams with $\mathrm{pH}$ above 4.9 (Horecký et al., 2002). This either indicates a sensitivity to ionic $\mathrm{Al}$ or the ability tolerate acid episodes below pH 5.0 rather than chronic acidity according to Braukmann's (2001) classification. The only mollusc in the spring-fed branch is the regionally most acid tolerant Pisidium casertanum, which can survive at $\mathrm{pH} 4.7$ and appears to be a calcifuge to some extent (Horsák, 2006). Though these species were likely part of the pre-acidification community of both branches, neither can be expected to successfully colonize the rain-fed branch in the near future.

On the other hand, many stoneflies, caddisflies and dipterans are classified as acid resistant. The stonefly Diura bicaudata is capable of tolerating permanently acidic waters and is classified as acid resistant (Braukmann, 2001), though Fjellheim and Raddum (1990) consider this species to be moderately sensitive, tolerating $\mathrm{pH}$ in the range of 5.0-5.5. Sim- ilarly, the dipteran larvae of the genus Dicranota, caddisfly larvae of the species Drusus annulatus, Chaetopteryx villosa and most of the genus Rhyacophila (except $R$. tristis) are acid resistant (Braukmann, 2001). Despite the presence of these taxa in other acidified neighbouring streams (Horecký et al., 2002) and in the spring-fed branch, they are absent in the rain-fed branch. As appears from a regional study (Horecký et al., 2006), these taxa can live in chronically acidified streams, but in low-humic waters only at $\mathrm{pH}>4.4$. Therefore, these are the most likely colonizers of the rain-fed branch as $\mathrm{pH}$ continues to rise, and can be considered "first indicators" of biological recovery. Recovery beyond what is predicted by this modelling would be necessary to allow the colonization of even the acid tolerant molluscs and mayflies, (e.g. Pisidium casertanum, Leptophlebia marginata) and for the return of brown trout (Salmo trutta).

\section{Conclusions}

Modelling shows an only very slow, gradual recovery of $\mathrm{pH}$ and alkalinity to the strongly acidified rain-fed branch of the Litavka River. While current deposition of acidifying compounds is already low, $\mathrm{SO}_{4}$ leaching from the soil, combined with depleted BS, will continue to prevent stream $\mathrm{pH}$ and alkalinity from recovering to their levels before 1860 . The influence of increased temperature in the catchment due to climate change will apparently have little impact on the prognosis for chemical recovery. However, other changes not incorporated into this modelling (e.g. forest decline or changes) could have significant impacts on the future course of recovery.

The macroinvertebrate composition in the rain-fed branch of the Litavka River reflects acidic conditions caused by the synergetic effect of acid precipitation, mainly long-term deposition of $\mathrm{S}$, intensified by spruce monocultures, in an acidsensitive catchment, with elevated $\mathrm{Al}$ concentrations along with low humic content in water. Chronically low water $\mathrm{pH}$ resulted in the absence of acid sensitive taxonomic groups such as molluscs, mayflies and crustaceans, and of acid sensitive stonefly and caddisfly species.

The species with highest potential to colonize the rain-fed branch of the Litavka are Diura bicaudata, Drusus annulatus, Chaetopteryx villosa, Rhyacophila praemorsa/polonica, and Dicranota sp. because of their tolerance of $\mathrm{pH}$ down to 4.4 and presence in less acid neighbouring running waters. Recovery of the rain-fed branch beyond what is predicted by our modelling would be necessary to enable the colonization of other species. 
Acknowledgements. We wish to thank the Czech Geological Survey for accessing part of their hydrochemical database, and D. Pychova at the Czech Hydrometeorological Institute for providing precipitation and temperature data from nearby meteorological monitoring sites. Climate data have been provided through the PRUDENCE data archive (EU contract EVK2-CT2001-00132). This research was supported by the Czech Science Foundation (GACR grant No. 206/04/P163 and 103/04/0214) and the Environment Project of the European Commission, EURO-LIMPACS (GOCE-CT-2003-505540). In addition, we would like to thank the many colleagues and students who have contributed in important ways to this research, including P. Chvojka, J. Špaček, J. Hájek, J. Hruška, J. Kulina, Z. Pehal, and J. Rucki.

Edited by: P. Dillon and R. F. Wright

\section{References}

Braukmann, U.: Stream acidification in South Germany - chemical and biological assessment methods and trends, Aquat. Ecol., 35, 207-232, 2001.

Čáka, J.: Střední Brdy - krajina neznámá, Mladá fronta, Praha, 159 pp., 1998.

Cosby, B. J., Ferrier, R. C., Jenkins, A., and Wright, R. F.: Modelling the effects of acid deposition: refinements, adjustments and inclusion of nitrogen dynamics in the MAGIC model, Hydrol. Earth Syst. Sci., 5, 499-518, 2001,

http://www.hydrol-earth-syst-sci.net/5/499/2001/.

Driscoll, C. T.: A procedure for the fractionation of aqueous aluminum in dilute acidic waters, Intern. J. Environ. Anal. Chem., 16, 267-284, 1984.

Engblom, E. and Lingdell, P. E.: The mapping of short-term acidification with the help of biological $\mathrm{pH}$ indicators, Rep. Inst. Freshw. Res., Drottningholm, 61, 60-68, 1984.

Evans, C. D., Monteith, D. T., and Cooper, D. M.: Long-term increases in surface water dissolved organic carbon: Observations, possible causes and environmental impacts, Environm. Pollut., 137, 55-71, 2005.

Fischer, D., Fischerová, J., and Švátora, M.: Mihule a ryby (Lampreys and fish), in: Střední Brdy, edited by: Cílek, V., Ložek, V., Škoda, A., et al., Př́bram, 151-154, 2005 (in Czech).

Fjellheim, A. and Raddum, G. G.: Acid precipitation: Biological monitoring of streams and lakes, Sci. Total. Environ., 96, 57-66, 1990.

Fott, J., Stuchlík, E., and Stuchlíková, Z.: Acidification of the Lakes in Czechoslovakia, in: Extended Abstracts of the International Workshop on Geochemistry and Monitoring in Representative Basins, edited by: Moldan, B. and Pačes, T., ČGÚ, Praha, 7779, 1987.

Fott, J., Pražáková, M., Stuchlík, E., and Stuchlíková, Z.: Acidification of lakes in Šumava (Bohemia) and in the High Tatra Mts. (Slovakia), Hydrobiologia, 274, 37-47, 1994.

Freeman, C., Evans, C. D., Monteith, D., and Fenner, N.: Export of organic carbon from peat soils, Nature, 412, 785-785, 2001.

Frost, S.: Evaluation of kicking technique for sampling stream bottom fauna, Can. J. Zool., 49, 167-173, 1971.

Hanaman, J.: Dissolved characteristics of running waters. Part 1: Hydrochemistry of the Ohre, Archív pro Přírodovědecký
Výzkum Čech, vol.9, no. 4, Dr. E. Grégr and F. Hřivnáč Press, Prague, 1986 (in Czech).

Havas, M. and Rosseland, B. O.: Response of zooplankton, benthos, and fish to acidification: An overview, Water Air Soil Poll., 85, 51-62, 1995.

Hämäläinen, H. and Huttunen, P.: Inferring the minimum $\mathrm{pH}$ of streams from macroinvertebrates using weighted averaging regression and calibration, Freshwater Biol., 36, 679-709, 1996.

Hart, S. C. and Perry, D. A.: Transferring soils from high- to lowelevation forests increases nitrogen cycling rates: climate change implications, Global Change Biol., 5(1), 23-32, 1999.

Herrmann, J., Degerman, E., Gerhardt, A., Johansson, K., Lingdell, P., and Muniz, I. P.: Acid-stress Effects on Stream Biology, Ambio, 22, 298-307, 1993.

Horecký, J., Stuchlík, E., Chvojka, P., Bitušík, P., Liška, M., Pšenáková, P., and Špaček, J.: Effects of acid atmospheric deposition on chemistry and benthic macroinvertebrates of forest streams in the Brdy Mts (Czech Republic), Acta Soc. Zool. Bohem., 66, 193-207, 2002.

Horecký, J., Stuchlík, E., Chvojka, P., Hardekopf, D. W., Špaček, J., and Mihaljevič, M.: Macroinvertebrate community and chemistry of the most atmospherically acidified streams in the Czech Republic, Water Air Soil Poll., 173, 261-272, 2006.

Horsák, M.: Mollusc community patterns and species response curves along a mineral richness gradient: a case study in fens, J. Biogeography, 33(1), 98-107, 2006.

Hruška, J., Moldan, F., and Krám, P.: Recovery from acidification in central Europe-observed and predicted changes of soil and streamwater chemistry in the Lysina catchment, Czech Republic, Environ. Pollut., 120, 261-274, 2002.

Hruška, J. and Krám, P.: Modelling long-term changes in stream water and soil chemistry in catchments with contrasting vulnerability to acidification (Lysina and Pluhuv Bor, Czech Republic), Hydrol. Earth Syst. Sci., 7, 525-539, 2003, http://www.hydrol-earth-syst-sci.net/7/525/2003/.

Kellomäki, S. and Väisänen, H.: Modelling the dynamics of the forest ecosystem for climate change studies in the boreal conditions, Ecol. Model., 97(1-2), 121-140, 1997.

Kopáček, J., Veselý, J., and Stuchlík, E.: Sulphur and nitrogen fluxes and budgets in the Bohemian Forest and Tatra Mountains during the Industrial Revolution (1850-2000), Hydrol. Earth Syst. Sci., 5, 391-405, 2001, http://www.hydrol-earth-syst-sci.net/5/391/2001/.

Kopáček, J., Stuchlík, E., Veselý, J., Schaumburg, J., Anderson, I. C., Fott, J., Hejzlar, J., and Vrba, J.: Hysteresis in reversal of Central European mountain lakes from atmospheric acidification, Water Air Soil Poll.: Focus, 2, 91-114, 2002.

Kopáček, J., Hardekopf, D., Majer, V., Pšenáková, P., Stuchlík, E., and Veselý, J.: Response of alpine lakes and soils to changes in acid deposition: the MAGIC model applied to the Tatra Mountain region, Slovakia-Poland, J. Limnol., 63(1), 143-156, 2004a.

Kopáček, J., Kaňa, J., Šantrůčková, H., Picek, T., and Stuchlík, E.: Chemical and biochemical characteristics of alpine soils in the Tatra Mountains and their correlation with lake water quality, Water Air Soil Poll., 153, 307-327, 2004b.

Křeček, J. and Hořická Z.: Degradation and recovery of mountain watersheds: the Jizera Mountains, Czech Republic, Unasylva, 207(52), 43-49, 2001.

Lepori, F., Barbieri, A., and Ormerod, S. J.: Effects of episodic 
acidification on macroinvertebrate assemblages in Swiss Alpine streams, Freshwater Biol., 48(10), 1873-1885, 2003.

Majer, V., Cosby, B. J., Kopáček, J., and Veselý, J.: Modelling Reversibility of Central European Mountain Lakes from Acidification: Part I - The Bohemian Forest, Hydrol. Earth Syst. Sci., 7, 494-509, 2003, http://www.hydrol-earth-syst-sci.net/7/494/2003/.

Moldan, B. and Schnoor, J.: Czechoslovakia: examining a critically ill environment, Environ. Sci. Technol., 26, 14-21, 1992.

Novák, M., Kirchner, J. W., Groscheová, H., Havel, M., Černý, J., Krejčí, R., and Buzek, F.: Sulfer isotope dynamics in two Central European watersheds affected by high atmospheric deposition of $\mathrm{SO}_{\mathrm{x}}$, Geochim. Cosmochim. Acta, 64, 367-383, 2000.

Økland, J. and Økland, K. A.: The effects of acid deposition on benthic animals in lakes and streams, Experientia, 42, 471-486, 1986.

Pehal, Z.: Hydrological and ionic balance of the source of the Litavka in the Brdy Mountains, Diploma Thesis, 111 pp., 2004 (in Czech).

Proe, M. F., Allison, S. M., and Matthews, K. B.: Assessment of the impact of climate change on the growth of Sitka spruce in Scotland, Can. J. For. Res., 26, 1914-1921, 1996.

Puhe, J. and Ulrich, B.: Global climate changes and human impacts on forest ecosystems, Ecological Studies 143, Springer, Berlin, 592 pp., 2001.

Sommaruga-Wögrath, S., Koinig, K. A., Sommaruga, R., Tessadri, R., and Psenner, R.: Temperature effects on the acidity of remote alpine lakes, Nature, 387, 64-67, 1997.

Stumm, W. and Morgan, J. J.: Aquatic Chemistry, Wiley, New York, 780 pp., 1981.

Tipping, E., Woof, E., Rigg, A., Harrison, P., Ineson, P., Taylor, K., Benham, D., Poskitt, J., Rowland, A. P., Bol, R., and Harkness, D. D.: Climatic influences on the leaching of dissolved organic matter from upland UK moorland soils, investigated by a field manipulation experiment, Environ. Int., 25, 83-95, 1999.
Townsend, C. R., Hildrew, A. G., and Francis, J.: Community structure in some southern English streams: the influence of physicochemical factors, Freshwater Biol., 13, 521-544, 1983.

UN-ECE.: Strategies and Policies for Air Pollution Abatement, Economic Commission for Europe (ECE.EB.AIR/65), Convention on Long-Range Transboundray Air Pollution, United Nations, New York and Geneva, 1999.

van Breemen, N., Jenkins, A., Wright, R. F., Arp, W. J., Beerling, D. J., Berendse, F., Beier, C., Collins, R., van Dam, D., Rasmussen, L., Verburg, P. S. J., and Wills, M. A.: Impacts of elevated carbon dioxide and temperature on a boreal forest ecosystem (CLIMEX project), Ecosystems, 1, 345-351, 1998.

Veselý, J. and Majer, V.: The effect of pH and atmospheric deposition on concentrations of trace elements in acidified freshwaters: A statistical approach, Water Air Soil Poll., 88, 227-246, 1996.

Veselý, J., Majer, V., and Norton, S. A.: Heterogeneous response of central European freshwaters to decreased acidic atmospheric deposition, Environ. Pollut., 120, 275-281, 2002.

Wright, R. F.: Effect of increased $\mathrm{CO}_{2}$ and temperature on runoff chemistry at a forested catchment in southern Norway (CLIMEX project), Ecosystems, 1, 216-225, 1998.

Wright, R. F. and Jenkins, A.: Climate change as a confounding factor in reversibility of acidification: RAIN and CLIMEX projects, Hydrol. Earth Syst. Sci., 5, 477-486, 2001, http://www.hydrol-earth-syst-sci.net/5/477/2001/.

Wright, R. F., Aherne, J., Bishop, K., Camerero, L., Cosby, B. J., Erlandsson, M., Evans, C. D., Forsius, M., Hardekopf, D. W., Helliwell, R., Hruška, J., Jenkins, A., Kopáček, J., Moldan, F., Posch, M., and Rogera, M.: Modelling the effect of climate change on recovery of acidified freshwaters: Relative sensitivity of individual processes in the MAGIC model, Sci. Total Environ., 365, 154-166, 2006. 